\title{
Critical Identity and Ethical Consciousness in the South African Indian Diaspora
}

\section{Rajendra Chetty}

\begin{abstract}
British imperialist rulers aimed to prove the ethnic pre-eminence of their race. In response, indentured labourers arriving in Natal as part of the Indian diaspora established and developed their own ethical standpoint. By analysing historical and literary elements, it is possible to trace the emergence of a critical identity and ethical consciousness which were shaped by the experiences of the South African Indian diaspora community. Such identity is memorable and transferable to the country as a whole, and of considerable value in nurturing social/ist consciousness for countering current challenges of racism and materialist indifference. This paper falls into two broad sections, the first deals with the history and context of South African Indian diasporic writings; the second section deals with diaspora identity.
\end{abstract}

Keywords: South African Indian; ethics; ethnicity; diaspora; identity

\section{Introduction}

The administration of this [African] quarter of the British Empire cannot be conducted on the principle of selfgovernment as that phrase is understood by white men. It must be more or less in the nature of an autocracy which leaves with rulers full responsibility for the prosperity of the ruled. The administration of India, where this aspect of the 
question has long been appreciated, is among the successes of which the British people, is most justly proud. The work done by England in Egypt is another proof of our capacity for autocratic rule (Lady Lugard ${ }^{1}$ 2012:1).

The British felt they had a duty to govern which was born out of their stifling sense of racial superiority, amply evidenced by Lady Lugard's (also known as Flora Shaw) statement above. Indian immigrants to Natal conflicted, almost at once, with the British government that promised to employ them fairly yet regarded them as no more than a dispensable commodity. This conflict grew for half a century until Mohandas Gandhi mobilised the Indian community in South Africa to resist oppressive laws. Britain's assumption of ethnic superiority was confronted directly by Gandhi's ethical standpoint. Gandhi's personal probity and public articulation of civil rights prevailed against the British administration not only in Natal and South Africa but in India as well. The following generation of his community in South Africa had to face an even more draconian form of racism, that of apartheid. His values were assimilated so thoroughly, and his wisdom inflected so deeply within the psyche of the Indian community that his political heirs lived to witness the collapse of that morally bankrupt regime.

Significantly, over the past twenty years, that is after liberation, several substantial works have emerged, which deal with the history and literature of the Indian struggle in South Africa and they include Fatima Meer's autobiography, Fatima Meer: memories of love and struggle (2017) and Monty Naicker's biography, Between Reason and Treason (2010). In 2007 Ashwin Desai and Goolam Vahed published the landmark volume, Inside Indenture, A South African Story, 1860-1914. In 2004, the collection of critical essays by Rajendra Chetty and Pier Paulo Piciucco, Indias Abroad, The Diaspora Writes Back appeared. The appearance of these narratives is in many ways a final, if somewhat belated, acknowledgement of a people's fight for civil rights and cultural recognition. This paper seeks, albeit in miniature, to highlight the intrepid resilience of a community that steadfastly opposed injustice under the British Empire and apartheid government, and in so doing crystallized a critical identity which is of great value in fostering democratic

${ }^{1}$ Flora Shaw is the wife of Sir Frederick Lugard, British colonial administrator of West Africa from 1895. 
and egalitarian principles nationally. Ellapen (2017) notes that the return to the indentureship experience in cultural production disrupts the linear progressive narrative of the post-apartheid nation by revealing how the traumas of the past resonate in the present and opens up questions around racial formations, memory, history, and national identity.

\section{Diaspora and Indenture}

Many who left India for Natal in South Africa in the nineteenth century did so as indentured labourers or girmitiyas. The 'passenger Indians', generally the merchant class, paid their passage. Vahed and Desai (2007) relate the history of three women labourers whose resilience typifies key aspects of Indian diaspora identity formation. The account of the women who arrived in Natal from India in 1902 is an example of the resourcefulness of human beings when pressed under the yoke of social discrimination on two counts; being women and being Indian during the British, male-dominated Raj. Mangah (94570) arrived from Vizagapatam in August 1902 with two adult women, Gurrama (94571) and Botchi Auki (94567) and her three children. Their migrant numbers were painted on boards held up before each labourer for their identity photograph. The numbers are a clear indication of the attempt to reduce the person to an object which was the purpose of the imperial indenture scheme. But these women soon proved their subjectivity and reclaimed their individuality. Many Indians were attracted to the five-year term of indenture by the beguiling advertisements posted in their homeland: little of which was true. The British had been unable to force the proud Zulus to work and their spears were still dripping with British blood as the aftermath of the victory at Isandlawana where over 1500 British soldiers succumbed to the Zulu warriors. Britain turned to India, the crown of the empire, as a source of cheap labour. The indenture scheme was in fact border-line slavery. Before joining the scheme, Botchi and her party had written ahead to friends. She had discovered it was essential to be assigned to one of the few humanely run farms and not one of the cruel establishments; of which there were many. When arriving in Durban, the party of women resisted allocation by officials. They remained adamant in the face of threats to send them back. Eventually, the Colonial Secretary himself intervened: they were allowed to join the relatives they wrote to originally on Barrow Green Farm in Port Shepstone. This ensured their safety and well-being. Desai and Vahed put it succinctly: 'Clearly there were 
Indians with sufficient nous to work the system to their advantage' (2007: 49).

Another example of the foundational elements of diaspora identity in South Africa is that of Rabos Bee (Indenture number 2397) who arrived in Natal from Madras in January 1864. In 1867 she married Goolam Hoosen and joined the Natal Government Railways as a clerk earning a salary of two pounds five shillings a month. She bought property in Victoria Street, Alice Street and Field Street. She opened and ran various businesses and by 1900 was the wealthiest businesswoman in Durban. She went on pilgrimage to Mecca in 1902. At the time of her death in 1916 she was worth ten thousand pounds. She had lived and prospered by her wits; successfully overcoming the disadvantages of her situation in the white-run Empire (Desai \& Vahed 2007:82).

Indian resistance at the sugar plantations of Reynolds brothers is another example of a growing political consciousness amongst the Indian community. The grand colonial mansion of Lynton Hall was the palatial home of the sugar baron Charlie Reynolds. His cruelty and inhumanity to the indentured workers on his vast estates meant he had the benefit of virtual slave labour with which to build up his empire of farms. Reynolds Brothers became the largest sugar producer in Natal. But labourers on his estates were not helpless victims. They created an underground network of informers who made the beatings and killings on the estate public knowledge. Little by little, the indentured labourers won the attention of the authorities until a formal enquiry was made into conditions at Lynton Hall estates. Charlie Reynolds was finally given an ultimatum in terms of the enquiry: no more labourers would be allowed to work on his lands as long as he was there. Charlie was effectively exiled. His brother took over. The patience, endurance and resilience of the indentured won the day. It was a turning-point for the history of Natal and crucial proof of the Foucauldian double-sidedness of any power relation. The subaltern had spoken, been heard and triumphed. Desai and Vahed write: 'The indentured, far from allowing the authorities to mould them into submissive instruments of labour, found many creative ways to resist, subvert, and even escape the system' (Desai \& Vahed 2007:144). The ethical had conquered the ethnic. Desai and Vahed have been careful to emphasize that these immigrants were not made by the history of their receptive country but were instead the makers of a central, if not core, element of what would become the new nation of the New South Africa. The nature of an ethical identity formed through such 
political trials is of great value in creating a climate of political accountability today.

\section{Diasporic Narratives}

The geographical diversity of the Indian diaspora has been shaped against the backdrop of the historical forces of colonialism, nationalism and neo-liberal globalisation (Hegde \& Sahoo 2017:1) Diaspora literature functions in a multitude of ways: historical record, a writing out of pain for the author, a way of understanding for the reader, a refraction of the hopefulness, the loss as well as expected gains, ambitions and fears. It helps to have such drastic changes expressed in words. Literature of the diaspora can heal by description and empathetic narratives just as it can explain to those outside the trauma of leaving, what it is to forfeit so much materially, existentially and emotionally. Voluntary or involuntary exile, willing departure or lachrymose farewell: all are the larger demarcations of saying goodbye, not knowing or being home, remembering and gradually forgetting. Recording and dramatizing such leaving is often the function of diasporic writing; narratives of diasporic struggle assuage the pain. Between generations there is an intimate history which evolves in the continuum of the unconscious mind, a private inheritance articulated from grandparent who bravely faced the new country, to recipient progeny who treasure the character of forebears as foundational model for the construction of their own identity. 'History' therefore functions in various ways in diaspora recollection: in the sense of historical record (annal), interpreted history (politicised record) and private domestic chronicle (identity formation). All three of these eddying currents interflow and rejoin each other in the ways of a veined corpus. Fictional writing of a diaspora is organic in this sense of a whole body with strongly interconnected public and private historical inflows.

In The Vintage Book of South African Indian Writing (Chetty 2010), for instance, many of the texts represented are overtly narrative yet covertly historical records, familial and cultural maps of radically re-shaped genetic continua. Such fictional accounts often relay a moment of severe re-casting of place, character and culture to form a new amalgam of identity. It is important to be sensitive to this re-shaping of private and communal consciousness in the process of editing. Writing ranges from the intensely fictional, through the socially mimetic, to the demonstrably political: the first is least time-bound and 
time-specific whereas the last is discernibly contained within an exact timeframe (an annal).

Indentured Indian labour in Natal was not only assigned to the sugar plantations, but also to coal mines. There was such extensive ill-treatment and neglect at the mines that the whisperings of satyagrahis (passive resisters) were quickly taken up. Women bravely spread the word: they threw a match to the tinder-box created by exploitative mine-owners. All histories are subjective; it is a narrative in its own way, by means of selection of detail and inevitable bias, so, conversely, fictional representation of diaspora periods can seldom be pure fiction but will be interlocked in historical reality. Because diaspora fiction, by definition, frequently chronicles traumatic, dramatic periods in people's histories, it is often time-specific in the more acknowledged sense of history. This paper-thin division between fiction and history can create a blurred area between private-consciousness and public fact. This indeterminacy is what draws so many to the genre.

Within this context of history as fiction and vice versa, short stories such as 'Grandmother's Feet', by Raazamah Pillay (2010), can be assessed. This particular story is complementary to the miners' strike as well as an independent work of art. The child in the story is third-generation diaspora, innocent of her privilege; she asks naively about her grandmother's splayed feet. 'Why is your small toe facing the other way, Ouwa? ${ }^{2}$ ' the little girl asks. This is not only the voice of a concerned relative but of one who is ignorant of the sacrifice of the first generation. Pillay's (2010) treatment of this question is on a knife-edge. If she dwells too long on the injustice of the coal-mines, she could easily turn the work of art into a harangue. Depicting self-pity may obscure the bravery which could both inspire readers from within the community and define it to the outside world. Too many tears will not assist close family or extended family to build a constructive identity. Pillay tells of how the great load of coal fell on Ouwa's feet. She does so with enough lifelike pain to make the old woman's suffering vivid. Yet she retains sufficient sense of the migrant's resilience to make the matriarch a role-model for her grandchildren. The tale is rooted in events of a particular time and is thus history. But, by its fictional nimbus, it encapsulates the plight of diasporas of many times and places. Pillay secures the sense of reparation, of survival and successful resilience, by ending her story with the epigram of the building

2 'Ouwa' is Telegu for grandmother. 
prowess of Nainah (Ouwa's husband). Pillay tells of the stone buildings left as a proof of Nainah's skill when he worked in Estcourt. His stone-masonry skills meant that there was a permanent tribute to him, and his people, in the town. This strength and craftsmanship translate the talents and resolve of one into the virtues of a community who did not collapse in misery but built, quite literally, a new place and meaning of place for themselves.

Because diaspora fiction is often liminally situated between fiction and historical account, sited within the interstices of angry expostulation, crumpled resignation, the definite and the indefinable, it may, at its most articulate, be not only extremely specific but also allusive, resonant and elusive. So Sita Gandhi's (2010) 'My Childhood at Phoenix Settlement' begins with a precise date and place, a local habitation and a name, but imaginatively calls up the spirit of her grandfather, the Jain warrior of individual and universal liberty; his private discipline was the key to freedom of the self and all. The story begins with the exact, the annal: 'I was born on 19 ${ }^{\text {th }}$ of October 1928' (Gandhi 2010:149). But it ends with the world of sacrifice, self-restraint and idealism: 'My father and his brothers had no carefree childhood and as a young man he was left alone here with the burden of his father's ideals on his young shoulders' (Gandhi 2010:158). At the start of the story, Sita Gandhi the narrator is the annalist, the family archivist as well as the spiritual purveyor of virtue and self-restraint. The spirit of Mahatma Gandhi, the good man, is almost at once re-kindled: 'My father was the only one left to run the Settlement as my Grandfather had wished it to be run as a non-money making place, to serve the Indian community. My father did so and he lived and died a poor man. Had he chosen he could have been a rich farmer or a rich printing press owner, but he chose to live as his father wished' (Gandhi 2010:149).

This desire for productive and virtuous community was a reality in the hundred-acre farm called the Settlement in Phoenix, Natal. It was a place of peace and honest collaboration - an Eden of sorts. It was in terrible contrast to Lynton Hall: the embodiment of the deceit and deceitfulness of the imperialist where profit was the defining end that justified the most inhumane means. Gandhi's collective farm housed the printing press for the newspaper Indian Opinion: it could not have been further removed from the exploitation and indifferent cruelty of the coal mines and sugar fields of Natal.

The memoir of Mohambry Naicker (2010) who was accused in the 1956 Treason Trial has a chapter entitled 'In the footsteps of the Mahatma'. At this point, literature and history meet. A personal record of trauma holds 
particular meaning for diaspora writing. There is a sense in which third and fourth generation beneficiaries need, and want, to know how their founder endured so much: whether it was a grandmother's crushed feet or an imprisoned paterfamilias. Naicker tells of how he answered the call of Gandhi to join the struggle: not this time against imperialist notions of ethnic preeminence but against quasi-Nazi attempts to prove white superiority: 'It was the voice of Mahatma Gandhi calling for action. Without any preparation, without any experience, without the slightest hesitation, I threw myself into the battle' (Naicker 2010:164). It was the conflict of ethnic versus ethical priorities. Naicker records the important moment of meeting Gandhi himself:

His teachings had become part and parcel of my life. His autobiography had been my Bible. We were ushered in his room by Mridula Sarabhai. Gandhiji was sitting cross-legged with the spinningwheel in front of him. We had come to meet the Father of the Indian Nation, and the welcome we received was naturally that of a dear father to his affectionate children (Naicker 2010:165).

True to form, Gandhi challenges his visitors to ethical endurance; the selfdiscipline that forms the core of his ethical warfare. They are asked if they would spend the night sleeping out of doors and join him for early morning prayers. But they are unable to rise at four in the morning and slept through instead (Naicker 2010:166).

\section{Indias Abroad - The Diaspora Writes Back}

The perspective of those analysing Indian diasporic fiction outside South Africa helps to create a larger, more comprehensible framework in which to review South African Indian history and fiction examined so far. A wider lens enables the reader to recognize familiar patterns. The bewilderment experienced by Natal Indian immigrant-workers has been repeated countlessly in the pain endured by other voyagers, exiles, emigrants or racial victims. The literary analyst of diasporic writing outside South Africa identifies patterns and significances in global narratives which focus on domestic annals and fictional representations. International perspectives and wider theoretical viewpoints can link South African texts to those of other countries in order to create an objective context. The question then arises as to the degree to which the analyst 
of the writer, or the writer of the experience of leaving, stresses the plight or prowess, the lament or the encouraging voice of resilience, or both.

Jaspal Singh's (2010) article, 'The Indian diaspora in Burma', is an example of the analysis of diasporic writing from outside South Africa as opposed to the South African texts examined so far. This provides a useful vantage point for viewing such texts as those of Sita Gandhi (2010) or Mohambry Naicker (2010). In her essay, Singh undertakes a critical analysis of Amitav Ghosh's The Glass Palace (2002) and Mira Kamdar's Motiba's tattoos (2002). In Ghosh's story, Dolly, a Burmese woman, is married to Rajkumar, a Bengali. Dinu (their son) was shouted at on the streets: they called him Zerbadi - which is a swear word for people who are half Indian, half Burmese (Singh 2010:53). Uma, an Indian woman from Calcutta, experiences intolerance while traveling around the country. - 'Everywhere she went she would see signs of a widening rift between Indians and their Burmese neighbours. Amongst students and nationalists and agitation was under way to separate Burma's administration from that of British India' (2010:53).

Similar to Singh's (2010) essay is Ahmed's (2004:70) discussion of Ghosh's The Shadow Lines (1988) where she quotes from Blunkett who 'can tell British Asians, more or less with impunity, that they should find marriage partners only from within Britain and that they should speak English in the home' (2004:73). Such racism crushes any attempt to appreciate the 'new' country as part of a global identity: to compensate for the loss of a single historically-rooted identity. Any hoped-for compensation of cosmopolitan being or world traveller is lost. Rushdie's dream of an international migrant is dashed by such bigots as Blunkett who crudely prescribes assimilation and proscribes bringing in any more 'of them'. Romantic ideas, and ideals, of synthesizing old and new identities, of enriching both former and present lands, of growing into a global citizen, are all foreclosed.

Literature of the diaspora can heal or at least relieve pain. Both writer and reader can be healed by the process of writing out hurt just as reader, immigrant or local resident, can be relieved by gaining greater understanding, by reading a verbalized, written version of immigrants' hardship. By speaking of Blunkett and letting others know about such racial prejudice, the writer, the analyst and the literary protagonist can claim to articulate injustice and thus exercise their resilience in the most essential way - they speak of it.

Rushdie articulates the condition of the migrant eloquently in Imaginary Homelands (1992), an essay which has become the locus classicus 
of the diasporic state - 'it's my present that is foreign, and ... the past is home albeit a lost home in a lost city in the mists of lost time' (1992:9). As the migrant/exile attempts to reclaim the lost home through the double filter of time and migration, the motherland that is remembered is no longer the one that was left behind, nor an invented one, but an imagined one:

But if we do look back we must also do so in the knowledge ... that our physical alienation from India almost inevitably means that we will not be capable of reclaiming precisely the things that were lost; that we will, in short, create fictions, not actual cities or villages, but invisible ones, imaginary homelands, Indias of the mind. (Rushdie 1992:10)

In similar vein, the protagonist Rita, in Vassanji's The Book of Secrets notes that the 'past matters, that's why we need to bury it sometimes. We have to forget to be able to start again' (1994:298). Rita makes the happiness she does not find. She acknowledges the past yet is prepared to stay its call upon the present. This preparedness is the cunning of survival rather than the purist's martyrdom on the altar of emotional truth. 'Burying the past' rings out as a mantra for so many of the valiant South African Indian women who knew they had to bury the past and endure present pain in order to secure a future for their children.

\section{Diaspora Identity}

Ronnie Govender draws attention to the issue of negotiating the past, integrating painful memory and vibrant present, in terms of the crucial matter of identity:

What was in the forefront was the problem of getting to grips with the cognizance of who Indians were. Were not 'Indians', first and foremost, South Africans? Were they acting in a way that seemed to indicate that they did not consider themselves true South Africans? (2008:20)

Indian villagers brought to South Africa have struggled to claim citizenship and identity, recognition and appreciation in this country for over 150 years 
despite extraordinary contributions to the structure and establishment of the nation. The agony of such injustice and the pain of claiming citizenship are at the heart of Govender's writings.

In 'Identity and belonging in Post-Apartheid South Africa: The Case of Indian South Africans', Vahed and Desai point out some of the sociological dangers facing the country:

1994 denoted the de-territorialisation of old apartheid racial identities. Race separateness was no longer codified in law and common citizenship was meant to glue all into a South African 'nation'... The present conjuncture opens possibilities to debate issues of identity and belonging. If access to resources continues to be defined exclusively by race then one can expect increasing frustration on the part of the poors who will most likely be susceptible to racial and ethnic overtures (2010:3).

The search for belonging, or as Fatima Meer puts it in her 2003 speech at the Diaspora Conference held in India, the longing for belonging, is a core concern of Govender's (2008) thought. His writings reflect the pain, anxiety and urgent desire that alternate in the search for home. The individual and collective odysseys of Indian migrants to South Africa span three centuries and include heartache, anger, injustice and joy by turns. The human need to belong, to call a place home, to associate freely with the beauty of a place and country, to identify fully, is fundamental to human beings yet has been denied to South African Indians in hurtful ways. Many hoped that the end of their five years of indenture would bring them freedom, or that the fall of the British empire would bring liberation, or the independence of India improve things somehow, or the end of apartheid herald universal franchise as well as tolerance. But well after these milestones came and went, matters may have improved in some aspects but the resistance and negativity remain in print and in voice despite the new constitution. The writings of Govender (2008) revivify the suffering of such reversal and rejection but his spirit of hope never flags. He forever holds out the banner of individual worth and final recognition. At the end of the play, 'The Lahnee's Pleasure' (Govender 1992) the stranger demarcates an area of independent thought free from the cringing subservience required by white imperialists.

Humiliation and ill-treatment marked indentured Indian lives from the 
moment of arrival in South Africa. The initial wrongs and attitudes of dislike have been documented right from the start on sugar estates such as Lynton Hall where English ladies minced through rose garden oblivious to labourers who expired in the canefields beyond or who clipped the pretty lawns they trod. Yet the sustained resentment of Zulus towards Indians is less regarded and generally avoided as too sensitive, not politically correct. So Edward Ramsamy in 2007 states, in a sanguine account of early Indian-Zulu relations, that 'Gandhi's settlement in Phoenix was in close proximity to the African population, and that Gandhi's contact with ANC's Langalibalele Dube led to a rejection of any feeling of racial superiority and increased his respect for the African people' (Ramsamy 2007:477). In the same year, 2007, however, Heather Hughes points out that Gandhiji's respect for Dube and readiness to learn from him were not returned by Dube:

Almost from the first issue of Ilanga, Dube made regular pronouncements about Indians (and allowed others to do the same). An item headed 'The Indian invasion' noted that 'we know by sad experience how beneath our very eyes our children's bread is taken by these Asiatics: how whatever little earnings we derive from Europeans, go to swell the purses of these strangers, with whom we seem obliged to trade ...' (Hughes 2007:54).

Dube's animosity is a disappointing attitude: his lack of receptivity dulls initiatives for reconciliation and hope of healing. Some may defend Dube by saying that such dark sentiments of racist resentment are time-bound: that such attitudes might not be seen today. Hughes suggests that the missionary station which schooled Dube may well have been the main cause of anti-Indian sentiment:

Perhaps the strongest anti-Indianism of all, however, was to be found at the Inanda mission station. The missionary in charge there from the 1840 s to the 1870 s was Daniel Lindley, in many ways no more liberal and tolerant than his missionary peers. A product of American Midwest religious revivalism, he was an anti-slavery republican, deeply committed to the upliftment of his African 'parishioners'. Yet on the issue of Indian immigration, he was less than liberal and 
tolerant: 'the great majority of these imported labourers will never return to their native land ... they are indescribably wicked, and seem to me hopelessly lost, now and forever .... I look upon these Indians as a growing cloud on our social horizon'. Other Inanda missionaries felt similarly (Hughes 2007:162).

The implications of Dube's vitriol for Indian settlers in South Africa are profound: such newly arrived immigrants to Africa had enough of a struggle to find an identity and meaning in a strange land without feeling unwanted and unwelcome.

Another great name in the firmament of leading minds and spirits in South Africa's history is Jan Smuts. As a founding member of the League of Nations, visionary of holism, universal co-operation and agreement, the Boer commando who was prepared to work for Empire and the greater good, might have been expected to regard Indian labourers with kindness and understanding given their contribution to the country's prosperity and cultural wealth. Yet such is Smuts's view of Indians in Africa:

South Africa is a little epic of European civilization on a dark continent. India is threatening this noble experiment with her vast millions .... All along the east coast of Africa from Mombasa to Durban, and ultimately to Cape Town they are invading, infiltrating, penetrating in all sorts of devious ways to reverse the role which we have thought our destiny (Marks 2000:216).

Smuts really does believe what he was told: that his white ancestors were bringing European civilization as a bright gift to a dark continent. He actually thinks of white people valiantly engaged in a noble experiment. He even considers the task of white settlement to be a destiny. The language he uses to describe Indian encroachment is telling at many levels. The word 'penetrating' has undoubted sexual connotations and signals many stereotypes of the insidious oriental threatening virgin white territory; land or womenfolk. A number of offensive patriarchal occidental prejudices are betrayed here. Edward Said's (1978) characterization of Western white attitudes is enacted in Smuts's view of Indian/orientals being devious vis-a-vis Anglo-Saxons and/or Christian men who are presumed to be uniformly straightforward, open and 
honest. Sub-consciously Smuts says more about Smuts and white folk generally than he does about Indians. spirit:

Govender contrasts Smuts's myopia with Gandhi's generosity of

Gandhi made a pair of sandals for his jailor, General Smuts. Was that not a far more powerful cultural statement than the dogged perpetuation of ethnicity on the oppressor's terms, under the guise of cultural survival? (2008:24).

It would be reassuring of the process of democratization if instances of negativity and ignorance such as exhibited by Smuts had waned. Regrettably, however, anti-Indian feeling and hate-speech continues unabated.

This thread of Indo-African tension was brought into the public domain in 2002 when playwright Mbongeni Ngema's 2002 song in Zulu, 'AmaNdiya' ('Indian'), attacked Indians for their alleged unwillingness to accept Africans as equals, for resisting change, being interested only in making money, and being exploitative. He protested the presence of post-1994 migrants from India and Pakistan and urged the 'strong men' of the Zulu nation to stand up to Indians. Lyrics such as 'we are faced with hardship and poverty because everything was taken by the Indians, but they turn around and exploit us' and 'Indians are abusive to Black people, being more racist than Whites', sounded a clear warning to Indians (Vahed \& Desai 2010:3).

From every side therefore, Zulu, English or Afrikaans, Indians were neither welcomed nor welcome. Recent remarks suggest the climate has not changed significantly. South African Indians have had to claw any rights they possess from ungracious hands.

Gopal, Khan and Singh, in their research into the nature of identity amongst today's Indian South African youth note that:

Notwithstanding the disruption of their belief system through Western teaching modalities in the disguise of modernity, Hindus re- 


\section{Rajendra Chetty}

invigorated their sense of religious identity by reconstructing their religious spaces through associational life under trying circumstances. In the post-apartheid South Africa, with the re-integration of the country on the global stage, contact with their ancestral land enjoyed resurgence (2014:29).

With regard to Christian identity, John Arun writes of the influence of missionaries on Indians:

It is important to observe some common experiences and issues faced by both Indians and ethnic South Africans during colonialism in South Africa. Both communities suffered injustices from the colonials. They came from poor and oppressed backgrounds. Both faced humiliations, as Indians were called 'Coolies' and Africans 'Kaffirs'. They both have undergone fear, dehumanisation, hunger and insult. They both carry the 'wounds' of past humiliations. Faith in Jesus Christ to a very great extent has helped them in healing their wounds. Today they are more competent to understand the wounds of their people. They are required together to play their role as the 'wounded healers' in the society (Arun 2007:255).

There are several worrying issues in this appeal for Indians to be wounded healers. The call for both groups to act as wounded healers is a serious difficulty. Why should anyone accept being 'wounded' as if that wounding is a fair part of life? There seems to be far too little sense of outrage at wrongs done. Even worse is the following statement in which Arun (2007) infers that thousands of Indians have chosen to convert not out of a profound sense of Jesus's love but as a means of gaining social respectability in another social forum. Concern with respectability rather than the passion for living out a deeply felt Love seems theologically questionable:

For Indian converts from depressed communities, conversion was a way forward for a new and a better future. The new future for them had to do with the discovery of a new social structure, which could provide them a new identity, self-respect and a new socio-spiritual world view. The motives of conversion for Indian converts can be 
understood as their need for a new respectable identity and an appropriate socio-spiritual worldview in which their generation could grow with dignity. However it is important to note that the depressed people took this route as per their own choice and accepted western culture as a new respectable identity over against their old caste identity in Hinduism (Arun 2007: 174).

The disrespect paid to Hinduism and lack of spiritual sensitivity align closely with the fear of difference and suspicion of the unknown seen earlier in missionary ignorance that nurtures Smuts's hatred of otherness. In fact Indians, in presenting another way of thinking and living comprise a catalyst for change and deeper understanding in South Africa. Immigrants who bring new ideas and challenge native habits of thought are a gift to the landscape and culture of a new country.

If Christianity has a poor groundwork for identity formation and dreams of egalitarianism are uncertain, many young Indian South Africans resort to images of glamour and superficiality alive in Bollywood. Older generation Indians are strongly opposed to young South Africans modelling their identity on a mode of internationalism, or Bollywoodism or the rootless diaspora. The transformational quality of Govender's (2008) theatre is meant to impact on the sense of being and identity of the audience. Authentic identity for a South African audience signifies for Govender (2008) a heightened social and private awareness of the individual and his or her role and duty in society; the many ways in which the individual can transform society for the better towards justice and probity, self-reliance. Govender (2008) wishes individuals to be active citizens who contribute to the society about them; not passive replicas of a fictitious and finally corrosive place of imaginary bling and superromance called Bollywood. Nevertheless, Bollywood has had a profound effect on the diaspora, especially among youth, globally. In Lourenco's (2017) study of Bollywood in Portugal, she noted that watching Hindi movies and copying dancing practices played an important role in the construction of alternative cultural identities:

The passion for Bollywood is integrated in the urban culture of ethnic consumption, together with a general interest in India. The idea of remediation, however, suggests the processes of cultural circulation and globalization as generators of people able to make cultural 


\section{Rajendra Chetty}

appropriations in accordance with their personal goals, thereby creating mediated cultural references. (Lourenco 2017:190)

The hope is that South Africa may provide an alternative and authentic identity for diaspora descendants from India. Brad Cibane raises interesting questions on the status of Indians in South Africa today.

There are two facts to consider. The first fact is that Gandhi's propaganda regarding Indians and Africans was not unique. Many Indians believed they should be treated better than Africans. The successive racist regimes in South Africa between 1860 and 1994 further entrenched this prejudice. The second fact is that while the apartheid system favoured Indians over Africans, it did not improve the lives of all Indians. Indians got better homes, better schools, better jobs but they were subject to similar economic, political and social prejudices (Cibane 2013).

Although Cibane may soften the terms of debate with his recognition of 'similar conditions', his claim that Indians thought themselves better than Africans or that they were favoured over Africans under apartheid are important points to consider. If one looks at the tri-cameral parliament as an example, Indians and Coloureds were favoured by the Apartheid regime over black people as part of the Afrikaner racist strategy to divide the populace along racial lines.

Imraan Buccus (2010) writes with remarkable clarity of the current predicament of South African youth. Buccus shows that the fight for equality is ongoing: not an achieved situation of permanent peace, sweetness and light:

It's not clear how the non-racialism cultivated in the Black Consciousness and trade union movements can be returned to the fore of civic life in contemporary South Africa. It still exists, of course, in the commitment, lives and work of many individuals. And it certainly still exists in some social movement politics. But the only thing that really seems to bind South Africans together these days is consumerism and the worship of bling. Consumerism can tie the children of the elites together, but for the majority who are not rich the culture of bling only compounds their sense of marginality and even 
desperation. The fact that so many young people are desperate is a real threat to nation building. There is always a grave risk that this desperation can be exploited by ethnic entrepreneurs hiding their fundamental complicity with racism behind the languages of culture, minority rights or even, on occasion, the left (Buccus 2010).

\section{Conclusion}

South Africans generally, and specifically those descended from indentured or passenger Indians, face a stark choice today: between the world of Lynton Hall or that communal ideal of Gandhi's Phoenix Settlement; between materialism, Bollywood, bling or an inner probity; between ethnicity or ethics; mindless consumerism or critical independence of thought. Diaspora writing such as Ronnie Govender's 'The Lahnee's Pleasure' makes the implications of such a choice plain. Both in the prose version and the original play script Govender contrasts the white life of sterile and loveless privilege in the characters of the owners of the hotel with the world of labour, justice and probity on the 'other side of the bar'. Pursuit of money, status and bling lead to the fraudulent, meaningless lives of those lahnees portrayed in his play. A commitment to an ethical life of sharing, political awareness and self-examination creates a continuum with the finest elements of the Indian diaspora's past: community and development of an authentic individual. The history of South African Indians leaves a unique legacy of strident political activism and critical thinking just as the writings reflect lives of self-sacrifice, ingenuity and resilience. Within the broad review of Indian diaspora records, that of South Africa stands out as a testament to remarkable ethical resistance and critical identity. Solutions to the current challenges of how to resolve interracial animosity and promote democracy may well be found by reflecting on the history and writings of the Indian diaspora, by identifying and replicating such ethical consciousness and critical literacy in schools and universities. This is the unfinished business of South African history.

\section{References}

Ahmed, R. 2004. Mapping London in Amitav Ghosh's The Shadow Lands. In Chetty, R. \& P.P. Piciucco (eds.): Indias Abroad: The Diaspora Writes 
Back. Johannesburg: STE Publishers.

Arun, J. 2007. The Impact of Religious Conversion on Cultural Identity Conversion. A Story of South African Anglican Indian Christians. Unpublished doctoral thesis, UNISA, Pretoria.

Buccus, I. 2010. Contested Indian Identity in Contemporary South Africa. In The Zoetendal Blog. Available at: https://zoetendal.wordpress.com/2010/ 05/03. (Accessed on 1 July 2016.)

Chetty, R. \& P.P. Piciucco (eds.), 2004. Indias Abroad: The Diaspora Writes Back. Johannesburg: STE Publishers.

Chetty, R. 2010. The Vintage Book of South African Indian Writing. Johannesburg: STE Publishers.

Cibane, B. 2013. Thought Leader. Mail and Guardian, May 29.

Desai, A. \& G. Vahed. 2010. Monty Naicker - Between Reason and Treason. Johannesburg: Shuter and Shooter.

Desai, A. \& G. Vahed. 2007. Inside Indian Indenture: A South African Story, 1860-1914. Cape Town: HSRC Press.

Ellapen, J.A. 2017. When the Moon Waxes Red: Afro-Asian Feminist Intimacies and the Aesthetics of Indenture. Small Axe, 21(2 53), 94-111.

Gandhi, S. 2010. My Childhood at Phoenix Settlement. In Chetty, R. The Vintage Book of South African Indian Writing. Johannesburg: STE Publishers.

Ghosh, A. 1988. The shadow lines. New Delhi: Ravi Dayal Publisher.

Ghosh, A. 2002. The glass palace. New York: Random House Inc.

Gopal, N., S. Khan \& S. Singh. 2014. Making Sense of Hindu Identity in South Africa. Diaspora Studies 7,1: 28-41.

Govender, R. 1992. The Lahnee's Pleasure. Johannesburg: Ravan Press.

Govender, R. 2008. In the Manure. New Africa: Cape Town.

Hegde, R.S. \& Sahoo, A.K. (eds.), 2017. Routledge Handbook of the Indian Diaspora. London: Routledge.

Hughes, H. 2007. The Coolies will elbow us out of the country: African Reactions to Indian Immigration in the Colony of Natal, South Africa. Labour History Review 72, 2: 60-81.

Kamdar, M. 2000. Motiba's tattoos: A granddaughter's journey from America into her Indian Family's past. New York: Plume Books.

Lourenco, I. 2017. Bollywood in Portugal: watching and dancing practices in the construction of alternative cultural identities. Etnografica 2,1: 175-202. Marks, S. 2000. White Masculinity: Jan Smuts, Race and the South African 
War. Raleigh Lecture on History. Proceedings of the British Academy 111: 201-23.

Meer, F. 2017. Fatima Meer: memories of love and struggle. Cape Town: Kwela Books.

Naicker, M. 2010. What I owe to Mahatma Gandhi. In Chetty, R. The Vintage Book of South African Indian Writing. Johannesburg: STE Publishers.

Pillay, R. 2010. Grandmother's Feet. In Chetty, R. The Vintage Book of South African Indian Writing. Johannesburg: STE Publishers.

Ramsamy, E. 2007. Between Non-racialism and Multiculturalism: Indian Identity and Nation-building in South Africa. Tijdscrift voor Economische en Sociale Geografie 98,4: 468-81.

Rushdie, S. 1992. Imaginary homelands: Essays and criticism 1981-91. London: Granta Books.

Said, E. 1978. Orientalism. New York: Pantheon Books.

Shaw, F. 2012. A tropical dependency. An outline of the ancient history of the Western Sudan with an account of the modern settlement of Northern Nigeria. Cambridge: Cambridge University Press.

Singh, J.K. 2010. The Indian diaspora in Burma and the politics of globalisation in Amitav Ghosh's The glass palace and Mira Kamdar's Mothiba's tattoos. In Singh, J.K. \& Chetty, R. Indian writers: Transnationalisms and Diasporas. New York: Peter Lang.

Vahed, G. \& A. Desai. 2010. Identity and Belonging in Post-Apartheid South Africa: The Case of Indian South Africans. Journal of Social Sciences. 25,1: $1-12$.

Vassanji, M.G. 1994. The B of Secrets. London: Picador.

Rajendra Chetty Literacy Development \& Poverty Cape Peninsula University of Technology chettyr@cput.ac.za 